\title{
Nursing protocol in transcatheter aortic valve implantation: care guideline ${ }^{a}$
}

\author{
Protocolo de enfermagem no implante de valva aórtica transcateter: um direcionamento \\ para o cuidado \\ Protocolo de enfermería en el implante de válvula aórtica transcateter: un direccionamiento \\ para el cuidado
}

\begin{abstract}
Giselle Cristina da Silva ${ }^{1}$
Denilson Campos de Albuquerque ${ }^{1}$

Ronilson Gonçalves Rocha ${ }^{1}(1)$

Ronald Teixeira Peçanha Fernandes ${ }^{2}$ (])

Luciana Cristina Lima Correia Lima ${ }^{3}$

Ana Paula Vieira Cabral ${ }^{3}$
\end{abstract}

1. Universidade do Estado do Rio de Janeiro.

Rio de Janeiro, RJ, Brasil.

2. Universidade Estácio de Sá.

Rio de Janeiro, RJ, Brasil.

3. Hospital Pró-Cardíaco.

Rio de Janeiro, RJ, Brasil.
Corresponding author:

Giselle Cristina da Silva.

E-mail: gisellec.rj@hotmail.com

Submitted on $12 / 04 / 2017$

Accepted on 07/04/2018.

DOI: 10.1590/2177-9465-EAN-2017-0260

\begin{abstract}
Objective: To validate a nursing care protocol by specialist nurses, contributing to the care delivered to patients undergoing percutaneous valve replacement. Methods: This cross-sectional, prospective, quantitative study adopted the Content Validity Index (CVI) to verify level of agreement regarding this protocol's total set of items. Results: The CVI obtained for each item of the protocol, verified using a validation instrument, was greater than the minimum required that is 0.80 , on average. Conclusion: The development of a protocol intended to guide care provided to patients who have undergone TAVI, improves patient safety and minimizes health problems, so that the implementation of specific strategies for the development of actions performed by nurses is essential.
\end{abstract}

Keywords: Nursing care; Aortic stenosis; Implantation of heart valve prosthesis

\section{Resumo}

Objetivo: Validar um protocolo de cuidados de enfermagem realizado por enfermeiros especialistas, contribuindo para a prática assistencial do paciente submetido à troca valvar percutânea. Métodos: Trata-se de um estudo metodológico, transversal e prospectivo, com abordagem quantitativa, que empregou o Índice de Validade de Conteúdo (IVC) para verificar o nível de concordância no conjunto total de itens do instrumento do protocolo. Resultados: Após a verificação com o IVC, para cada item do instrumento de validação do protocolo, os valores obtidos em relação a todos os itens ficaram, em média, maiores que o mínimo para o IVC, que é acima de 0,80. Conclusão: O desenvolvimento de um protocolo de cuidados, voltado para os pacientes submetidos ao TAVI, possibilita o aumento da segurança destes e minimização dos agravos à saúde, sendo um fator essencial na implementação de estratégias específicas nas ações desempenhadas pelo enfermeiro.

Palavras-chave: Cuidados de enfermagem; Estenose aórtica; Implante de prótese de valva cardíaca.

\section{Resumen}

Objetivo: Validar un protocolo de cuidados de enfermería por enfermeros especialistas, contribuyendo para la práctica asistencial del paciente sometido al cambio de válvula percutánea. Métodos: Se trata de un estudio metodológico, transversal y prospectivo, con abordaje cuantitativo, que empleó el Índice de Validez de Contenido (CVI) para verificar el nivel de concordancia en el conjunto total de ítems del instrumento del protocolo. Resultados: Después de la verificación con el CVI para cada ítem del instrumento de validación del protocolo, los valores obtenidos en relación a todos los ítems del protocolo, quedaron con los valores, en media, mayores que el mínimo para el CVI, que es arriba de 0,80. Conclusión: El desarrollo de un protocolo de cuidados dirigido para los pacientes sometidos a TAVI, posibilita el aumento de la seguridad del paciente minimiza los daños a la salud, siendo un factor esencial en la implementación de estrategias específicas para el desarrollo de acciones desempeñadas por el enfermero.

Palabras clave: Cuidados de enfermería; Estenosis aórtica; Implante de prótesis de válvula cardíaca. 


\section{INTRODUCTION}

The population segment with the most growth in Brazil is the elderly. The elderly population will triple within 40 years and surpass the current level of 19.6 million (10\% of the Brazilian population) by 2050 (29.3\%). Estimates show that the population profile will reverse in 2030 when both the absolute number and percentage of Brazilian individuals 60 years old or older will surpass that of children aged from 0 to 14 years old. ${ }^{1}$

Rapid aging of the population will result in changes both in terms of the epidemiological profile and age structure, in which non-transmissible chronic diseases (NTCD) will predominate. ${ }^{2}$ NTCDs account for $72 \%$ of deaths, representing the health problem of greatest magnitude. ${ }^{3}$ Among NTCDs, cardiovascular diseases are the main cause of death in Brazil, even as mortality due to these diseases has decreased over the years. ${ }^{4}$

Among cardiovascular diseases, degenerative Aortic Stenosis (AoS) is the valve disease most frequently found in developed countries. ${ }^{5}$ Estimates are that the prevalence of AoS is close to $5 \%$ among adult populations aged over 75 years of age. ${ }^{6}$ Open heart surgery with valve replacement, using a metallic or biological prosthesis, is the treatment considered to be the gold standard, promoting improved quality of life and greater rates of survival. ${ }^{7}$ Surgery represents a high risk for older patients with other comorbidities, with perioperative mortality up to $50 \%$. Transcatheter aortic valve implantation (TAVI) is considered an alternative treatment for high surgical risk patients with degenerative AoS, as this procedure decreases symptoms and improves life expectancy. ${ }^{8}$

TAVI is a new procedure in which a bioprosthetic valve is inserted through a catheter and implanted within the diseased aortic valve. ${ }^{9}$ Replacing the aortic valve by transcatheter is undoubtedly the most exciting recent advancement in interventional cardiology and cardiovascular surgery. ${ }^{10}$

Nursing care should be individualized for certain patient conditions. The development and implementation of protocols is an alternative intended to aid necessary actions, favoring the planning of care and, consequently, care delivery. ${ }^{11}$

Protocols are guidelines systematically developed to assist in the delivery of care for a given health problem in a specific clinical circumstance. The adoption of evidence-based protocols enables more qualified healthcare workers to achieve better health outcomes, while also enabling them to deal with the growing incorporation of technology in health care delivery. ${ }^{11,12}$

Therefore, this study is intended to contribute to care delivery by asking specialist nurses to validate a protocol of nursing care to be incorporated in the care routine of staff working with valve replacements, promoting the identification of complications and facilitating the management of potential intercurrences or adverse events. Thus, this study's objective was to validate a nursing care protocol by specialist nurses, contributing to the care delivered to patients undergoing percutaneous valve replacement.

\section{METHOD}

This methodological, cross-sectional and prospective study with a quantitative approach was conducted in a private hospital located in Botafogo in the city of Rio de Janeiro, RJ, Brazil a hospital that is a reference for high complexity treatment.

Expert nurses (the study participants) from the postoperative and hemodynamic sectors, with at least two years of experience in the field and a specialization, were invited to assess the protocol. The nurses who consented received free and informed consent forms, the instrument to assess the protocol, and the care protocol suggested by the authors.

The nurses assessed the protocol and inter-rater agreement was determined, based upon which a Content Validity Index (CVI) was calculated for each of the items and for the entire set of items, so that an agreement index for the entire protocol was established. ${ }^{13}$ The protocol's items concerning the content assessment were: content validity and relevance; clarity of items; and scope of content.

Content validity enables verifying whether the instrument accurately measures what it is intended to measure. Content relevance verifies whether the protocol's items comprise all aspects related to what it is expected to measure; clarity of items refers to whether the way the protocol is developed favors understanding; and scope of content shows whether the protocol comprises all the items related to what it is expected to assess. ${ }^{13}$

$\mathrm{CVI}$ is a frequently used method in the health field. It allows researchers to measure the proportion or percentage of participants who agree with certain aspects of an instrument and its items. It initially enables analyzing each item individually and then the instrument as a whole. ${ }^{14} \mathrm{~A}$ Likert scale, proposed by Rensis Likert in 1932, is used in this method to measure attitudes. The scale contains statements related to the objective under study and the participants are asked whether they agree or disagree with the statements, reporting their level of agreement or disagreement, attitude toward each item by checking from 1 to 4 or from -2 to 2 . To assess relevance/representativeness, answers include scores that range from: $1=$ not relevant or not representative; $2=$ item requires large review to be considered representative; $3=$ item requires small review to be considered representative; $4=$ item relevant or representative. ${ }^{14}$

The index is calculated by totaling agreement obtained by items for which the experts checked " 3 " or "4". The items that score "1" or "2" must be revised or deleted. Thus, the CVI is also defined as "the proportion of items to which the study's participants assign a score 3 or $4 "$ ". The formula to assess each item individually is: $\mathrm{CVI}=$ number of answers with a 3 or 4 divided by the total number of answers. The minimum level of agreement required to validate new instruments is $0.80 .{ }^{16}$

The items that did not reach this rate were modified by the authors in accordance with the experts' suggestions. Data were treated using Microsoft Office 365 Excel $^{\circledR}$ and statistically analyzed using SPSS for Windows (version 22.0). 
The study was submitted to the Institutional Review Board at the University of the State of Rio de Janeiro (UERJ) and Pró-Cardíaco Hospital (opinion reports Nos. 2.051.273 and 2.082.236. All information related to the study was kept confidential, as were the participants' identities.

\section{RESULTS AND DISCUSSION}

The postoperative sector is composed of 28 nurses divided into on-call and routine workers and the service coordinator, while the hemodynamics sector is composed of two nurses only. A total of 30 questionnaires to assess the TAVI protocol were distributed, along with free and informed consent forms. After the period established for the study (30 days), 18 properly completed questionnaires were returned along with their respective signed informed consent forms. After reading and verifying whether inclusion criteria were met, one questionnaire was excluded because it did not meet the study's specifications, so that 17 questionnaires that met the study's objectives remained. The number of participants (experts in the field) often depends on how many people are available and how many to whom the author of the instrument has access; that is, the number of participants is not based on the existing population of professionals. Five experts enable a sufficient level of control for the probability of agreement of the items under study. ${ }^{17}$

Most participants were female (70.6\%). The predominance of women in the nursing field is reported by other authors, reflecting a historical characteristic of this profession, in that, since its beginnings, it has been a profession adopted almost exclusively by women. ${ }^{18}$ In terms of age, women were 35.88 years old, on average, with minimum of 26 and a maximum 51 years old, a notably young age group.

In regard to the sector in which these participants worked, $88.24 \%$ were from the postoperative sector, where patients who had undergone TAVI are transferred immediately after the procedure. Postoperative units of cardiac surgery present innovative and specialized nursing care that is provided to critical patients, who require specific, safe and continuous care practices. Nurses from these units perform multiple tasks with a high level of demand and responsibility, which, depending on their knowledge, skills and attitudes, may positively or negatively interfere in the care provided to the patient. ${ }^{19}$

A total of $11.76 \%$ of the study's participants were from the hemodynamic sector, the unit where the procedure is performed. The nurses working in the hemodynamic unit perform care, managerial, teaching and research tasks. These nurses provide direct care to patients, being responsible for all the care provided during the procedure and must be attentive to potential intercurrences. ${ }^{20}$

The participants' professional experience ranged from 2 to 15 years. A share $(40.6 \%)$ of the nurses has from 2 to 5 years of experience, $(23.5 \%)$ from 6 to 10 years, $(11.8 \%)$ from 11 to 15 years, and $(23.5 \%)$ more than 15 years; there is an average of
2.18 years of experience. Professional experience, institutional involvement, and stability acquired with time encourage these professionals to remain in this organization, while the period of time working in a given facility may be associated, based on our experience, with the institution's work proposal, and individual satisfaction. ${ }^{21}$

The nurses' experience, knowledge, skills, and experience concerning what one wants to validate are important aspects that need to be taken into account. Therefore, a detailed description of selection criteria applied to experts is an essential step in studies validating diagnoses, interventions or outcomes, to ensure the reliability of findings, as well as to enable the replication of results by other researchers. ${ }^{22}$

Table 1 presents the $\mathrm{CVI}$ that concerns the questions of the protocol of nursing care provided to patients who have undergone TAVI.

In the assessment of the protocol's first item, which involves the assessment of vital signs, the participants agreed in regard to content validity $(\mathrm{CVI}=0.99)$ and relevance $(\mathrm{CVI}=0.95)$, clarity $(\mathrm{CVl}=0.96)$, and content scope $(\mathrm{CVl}=0.94)$. Agreement in regard to this item is explained because vital signs are important indicators of health and indicate body functions. These parameters, when regularly measured, help nurses to identify nursing diagnoses, assess interventions, and make decisions regarding patients' responses to therapy. ${ }^{23}$

In the item neurological assessment, agreement was also obtained for content validity $(\mathrm{CVl}=0.96)$, relevance $(\mathrm{CVl}=0.89)$, clarity $(\mathrm{CVI}=0.94)$, and scope of the content $(\mathrm{CVI}=0.78)$. The last $\mathrm{CVI}$ is explained by the fact that two participants were unsure about when this assessment should be performed and another two participants understood that applying the Glasgow Coma Scale (GCS) was not necessary considering that the patients are under sedatives and for this reason they applied the Ramsay Sedation Scale, instead.

The Glasgow Coma Scale (GCS) is applied worldwide to identify neurological dysfunction and monitor a patient's level of consciousness; predict prognosis; and standardize language among health workers. ${ }^{24}$ The Ramsay scale is more frequently used to assess an individual's level of sedation and is based on clinical criteria that are scored from 1 to 6 , rating the individual's level of anxiety, agitation or both, up to an unresponsive coma. ${ }^{25}$ Authors report five transcatheter aortic valve implantations from July to November 2009 that used conscious sedation. ${ }^{26}$

Additionally, considering this protocol is valid for the 48 hours of hospitalization, patients are not under the effect of sedation for the entire period. Nevertheless, the aforementioned situation led to the addition of another sub-item to this care protocol - the implementation of the Ramsay Sedation Scale, which was one of the participants' suggestions.

Agreement was also obtained on item 3, which refers to respiratory assessment, in terms of content validity $(\mathrm{CVI}=0.96)$, relevance $(\mathrm{CVI}=0.93)$, clarity $(\mathrm{CVI}=0.88)$, content scope $(\mathrm{CVl}=0.85)$. This level of agreement shows the importance of 
Table 1. CVI of items of the protocol of nursing care provided to patients who have undergone TAVI

Items assessed

\begin{tabular}{|c|c|c|c|c|}
\hline Questions on the instrument used to validate the protocol's content & $\begin{array}{c}\text { Content } \\
\text { validation }\end{array}$ & Relevance & Clarity & $\begin{array}{c}\text { Content } \\
\text { scope }\end{array}$ \\
\hline $\begin{array}{l}\text { 1. Does the vital signs assessment proposed by the protocol meet the } \\
\text { objectives proposed? }\end{array}$ & 0.99 & 0.95 & 0.96 & 0.94 \\
\hline $\begin{array}{l}\text { 2. Does the neurological assessment comprise the assessment of } \\
\text { level of consciousness, pupillary evaluation, sudden signs of stroke, }\end{array}$ & 0.96 & 0.89 & 0.94 & 0.78 \\
\hline
\end{tabular}

Glasgow Coma scale, and sleep patterns?

3. Does the protocol consist of an assessment of respiratory rate, respiratory sounds, spontaneous ventilation, whether the patient is receiving oxygen therapy or mechanical ventilation, whether

$\begin{array}{llll}0.96 & 0.93 & 0.88 & 0.85\end{array}$ the patient needs his/her airways to be aspirated, care concerning leaving the headboard raised and in regard to chest drains?

4. Composed of continuous monitoring of heart activity, electric conduction and/or heart rhythm; ECG performed after the procedure, every 12 hours, and when in pain; transvenous cardiac pacing; 0.96 0.91 0.78 chestpain; assessment of cardiac enzymes; and whether there was cardiorespiratory arrest after the procedure?

5. Does gastrointestinal assessment include verifying whether the patient is fasting or his/her diet has been released; checking diet characteristics, whether the patient is having an enteral diet; recording the presence of nauseas; loss of appetite; and date of the 0.98 $9.98 \quad 0.88$ 0.88 last bowel movement?

6. Does renal assessment include establishing rigorous fluid balance; assessing urine output; assessing signs of renal injury; implementing nephroprotection; and controlling intravenous infusion?

$\begin{array}{llll}1.00 & 0.99 & 0.92 & 0.93\end{array}$

7. Does the hematologic/vascular assessment include aspects related to the description of accessing the site, whether there is a pulse is present, peripheral perfusion, hematoma, bleeding, limb's coloration and temperature; monitoring levels of hemoglobin, hematocrit and platelet; collection of pre-transfusion blood sampling; keeping the limb extended during the first 12 hours after the procedure; and assessing bleeding in oral mucosa, feces, ecchymosis, and urine?

8. Does the pain assessment include aspects related to the presence of pain after the procedure; sudden pain; and administration of analgesics if pain is scored greater than 4 on the numerical verbal scale?

9. Does this segment include aspects related to decubitus; HGT verification; keeping the patient on bed rest for the first 24 to 48 hours after the procedure; and administrating antibiotics and antiplatelet agents?
0.87
0.86
0.66
0.71

Source: Developed by Giselle Cristina da Silva, in her Master's thesis “Nursing Protocol in aortic valve percutaneous replacement: direction for care.” 2017.

assessing this item, considering the respiratory system's main function is to promote gas exchange and these parameters are essential to a patient's full and satisfactory recovery. ${ }^{27}$ Approximately (29.4\%) of the participants assessing this protocol suggested some aspects be included, such as: assessment of respiratory rate and information regarding chest drainage: oscillation, drained volume; endotracheal tube cuff pressure; subglottic aspiration; and tracheostomy.
Nurses significantly contribute to the treatment of patients with respiratory changes by performing anamnesis and physical chest examinations. This assessment enables the establishment of an information base and ensures the detection of potential changes in a patient's respiratory patterns. Because nurses are closer to patients, they are the professionals who more often detect clinical changes. ${ }^{27}$ 
The following levels of agreement were obtained in regard to cardiac assessment: content validity $(\mathrm{CVI}=0.96)$; relevance $(\mathrm{CVI}=0.91)$; clarity $(\mathrm{CVI}=0.78)$; and scope of content $(\mathrm{CVI}=0.78)$. The level of agreement regarding clarity and scope of content was slightly lower (35.29\%) because the participants suggested recording the parameters of transvenous cardiac pacing, such as: exercising care in patients' mobility due to the risk of catheter dislodgement; the risk of the patient becoming dependent on it; and the duration of transvenous cardiac pacing for the patient. Some (17.6\%) participants suggested specifying that the ECG be conditioned to chest pain and not to just any type of pain. In regard to the sub-item "Cardiac Enzymes", some (5.8\%) participants asked for it to be clearer, such as by describing which enzymes are assessed in the 24-hour period after the procedure.

Cardiologic assessment is of paramount importance because the symptoms that patients manifest establish the priority of care. The cardiovascular system plays an important role in maintaining the body and its primary function is to bring oxygenated blood to tissues and remove blood that has $\mathrm{CO}_{2} \cdot{ }^{27}$

Cardiac pacemakers return quality of life and change the prognosis of patients with bradyarrhythmias or potential deleterious disorders that affect the cardiac conduction system. ${ }^{28}$ Temporary transvenous pacing aids balloon aortic valvuloplasty and/or prosthesis implantation by inducing tachycardia, remaining in demand for 48 hours, thus, avoiding greater problems related to conduction disorders. ${ }^{26}$

Full agreement was obtained in regard to the gastrointestinal assessment, with results of content validity $(\mathrm{CVI}=0.98)$, relevance $(\mathrm{CVI}=0.96)$, clarity $(\mathrm{CVI}=0.88)$, and scope of content $(\mathrm{CVI}=0.88)$. Even though CVI was satisfactory, some (35.2\%) participants suggested adding the sub-item: characteristics of oral diet; use of medication to provide gastric protection; position of the nasoenteral tube; and the presence of peristalsis. These items are very important for nurses to assess gastrointestinal function because having knowledge of a patient's health changes by collecting and interpreting findings, which is key to supporting care delivery. ${ }^{27}$

Renal assessment also obtained satisfactory agreement in terms of content validity $(C V I=1.0)$, relevance $(C V I=0.99)$, clarity $(\mathrm{CVl}=0.92)$, and scope of content $(\mathrm{CVl}=0.93)$. Assessing the renal system is extremely important because this system is responsible for maintaining the body's homeostasis, as it frees the body from degrading products that are ingested or produced and controls the volume and composition of body fluids. ${ }^{29}$

The hematological/vascular assessment was the item in this protocol that obtained the lowest level of agreement: content validity $(C V I=0.87)$, relevance $(C V I=0.86)$, clarity $(C V I=0.66)$, and scope of content (CVI=0.71). The participants $(41.1 \%)$ suggested including or changing sub-items, thus the CVIs are below what is considered the minimum for validation. Considering the total number of experts, $17.6 \%$ suggested that the interval between verification of pulse, perfusion, presence of hematoma and bleeding, and skin's coloration and temperature should be increased. The protocol suggests assessing these aspects every
15 minutes in the $1^{\text {st }}$ hour, every 30 minutes in the $2^{\text {nd }}$ hour, and every hour after the $3^{\text {rd }}$ hour.

Vascular complications represent (26\%) of the complications that patients who undergo TAVI experience, also accounting for the highest number of adverse events in this procedure. Many studies report such complications and for this reason there is a need to intensively assess the early signs of hematological complications, as suggested in the protocol. ${ }^{30}$

The item concerning pain assessment obtained agreement from all the participants: content validity $(\mathrm{CVI}=0.99)$, relevance $(\mathrm{CVI}=0.95)$, clarity $(\mathrm{CVI}=0.95)$, and scope of the content $(\mathrm{CVI}=0.95)$. Adjustments suggested include the inclusion of pain assessment every four hours, and non-pharmacological measures to decrease patient pain.

In January 2000, the Joint Commission on Accreditation of Healthcare Organizations (JCAHO) published a guideline describing pain as the $5^{\text {th }}$ vital sign. Because of the proximity of the nursing staff to patients, these professionals identify, assess, and report pain, plan pharmacological therapy, prescribe nonpharmacological measures, and assess analgesia. Thus, in practice, nurses are those who organize pain management. ${ }^{31}$

Agreement on item additional assessments was for content validity $(C V I=0.94)$, relevance $(C V I=0.95)$, clarity $(C V I=0.79)$, and scope of content $(\mathrm{CVI}=0.91)$. Clarity obtained a lower CVI because the participants understood that the position in which the item is assessed implies that it is part of the respiratory assessment. According to suggestions, the item additional assessments was removed from its original place and placed in a position where it is clear and leaves no doubt as to its assessment.

The last item of the protocol refers to whether the participants recommend it be implemented in practice. All the participants recommend the use of the protocol, with most $(64.7 \%)$ recommending its implementation as it is and the rest $(35.3 \%)$ recommending its implementation after changes. The approval on the part of the participants reveals a need to implement the protocol in the delivery of care to improve quality of care and decrease harm caused by non-assessment of items that are important for patient recovery. Annex shows the protocol of nursing care provided to patients who undergo TAVI suggested by the study's participants. After assessing the CVI for each item of the protocol, the following means were obtained for content validity (0.96), relevance (0.93), clarity (0.86), and scope of content $(0.85)$. All the items obtained a mean that was greater than the minimum required, that is $\mathrm{CVIs}$ were greater than 0.80 . Those items that obtained lower levels of agreement were included after implementing the participants' suggestions. The mean agreement obtained for all the items of the protocol was (0.90), showing the protocol is strongly relevant to the practice of professionals and is useful for nurses providing care to patients who have undergone TAVI. Protocols are not intended to fragment, generalize or "toughen" nursing care, but rather to provide actions that go from the general to the specific, guiding nursing care in an attempt to meet all the needs patients may present in such a condition. ${ }^{11}$ 
The protocol's final version that includes the experts' suggestions is presented in the form of a supplement to this paper.

\section{CONCLUSION}

We highlight in this study that, within the multi-professional team, nurses are the professionals responsible for providing postoperative care and for identifying complications, while it is essential such care be provided quickly and directed to correcting problems. The more aware nurses are of potential complications, the earlier they are able to address them.

The protocol was validated by specialist nurses in the field, who were able to check all the items and provide technicalscientific contributions they acquired over the course of their professional experiences.

Transcatheter aortic valve implantation (TAVI) is a technique established with precise indications and is in a phase of expansion, offering improved quality of life to patients with degenerative AoS who cannot undergo conventional surgery. The development of a care protocol directed to patients who undergo TAVI improves patient safety and quality of care delivery and minimizes harm, so that the implementation of specific strategies to develop actions nurses perform in hospital units is essential.

\section{REFERENCES}

1. Instituto Brasileiro de Geografia e Estatística (IBGE). Mudança demográfica no Brasil no início do século XXI - Subsídios para as projeções da população. Rio de Janeiro (RJ); 2015 [cited 2016 Jun 22]. 102 p. Available from: http://biblioteca.ibge.gov.br/visualizacao/ livros/liv93322.pdf

2. Pilger $\mathrm{C}$, Menon MU, Mathias TAF. Capacidade funcional de idosos atendidos em unidades básicas de saúde do SUS. Rev Bras Enferm [Internet]. $2013 \mathrm{Nov/Dec}$; [cited 2016 Jun 22]; 66(6):907-13. Available from: http://www.scielo.br/scielo.php?script=sci_arttext\&pid=S003471672013000600015\&lng=en. DOl: http://dx.doi.org/10.1590/S003471672013000600015

3. Ministério da Saúde (BR). Secretaria de Vigilância em Saúde. Departamento de Análise de Situação de Saúde. Plano de ações estratégicas para o enfrentamento das doenças crônicas não transmissíveis (DCNT) no Brasil 2011-2022/Ministério da Saúde. Secretaria de Vigilância em Saúde. Departamento de Análise de Situação de Saúde. Brasília (DF): Ministério da Saúde; 2011 [cited 2016 Jun 22]. 30 p. Available from: http://bvsms.saude.gov.br/bvs/ publicacoes/plano_acoes_enfrent_dcnt_2011.pdf

4. Instituto Brasileiro de Geografia e Estatística (IBGE). Percepção do estado de saúde, estilos de vida e doenças crônicas - Pesquisa Nacional de Saúde. Rio de Janeiro (RJ); 2013 [cited 2016 Jun 22]. 35 p. Available from: http://biblioteca.ibge.gov.br/visualizacao/livros/ liv91110.pdf

5. Lemos PA, Mariani Jr J, Esteves Filho A, Kajita LJ, Cardoso LF, Dracoulakis MDA, et al. Implante transcateter de valva aórtica sem a necessidade de marca-passo definitivo em uma série de casos consecutivos: é possível predizer o risco de bloqueio atrioventricular? Rev Bras Cardiol Invasiva [Internet]. 2010 Apr/Jun; [cited 2016 Jun 22]; 18(2):135-9. Available from: http://www.scielo.br/scielo.php?script=sci arttext\&pid=S2179-83972010000200006\&lng=en. DOI: http://dx.doi. org/10.1590/S2179-83972010000200006
6. Sarmento-Leite R, Quadros AS, Prates PRL, Zanatta LG, Salgado Filho $\mathrm{PA}$, Grando T, et al. Implante valvular aórtico percutâneo: experiência inicial do Sul do Brasil. Rev Bras Cardiol Invasiva [Internet]. 2008; [cited 2018 Apr 22]; 16(4):398-405. Available from: http://www.scielo.br/scielo. php?script=sci_arttext\&pid=S2179-83972008000400007\&lng=en DOI: http://dx.doi.org/10.1590/S2179-83972008000400007

7. Bonow RO, Carabello BA, Chatterjee K, de Leon AC Jr, Faxon DP, Freed MD, et al.; 2006 Writing Committee Members; American College of Cardiology/American Heart Association Task Force. 2008 Focused update incorporated into the ACC/AHA 2006 guidelines for the management of patients with valvular heart disease: a report of the American College of Cardiology/American Heart Association Task Force on Practice Guidelines (Writing Committee to Revise the 1998 Guidelines for the Management of Patients With Valvular Heart Disease): endorsed by the Society of Cardiovascular Anesthesiologists, Society for Cardiovascular Angiography and Interventions, and Society of Thoracic Surgeons. Circulation [Internet] 2008 Oct;118(15):e523-e661. Available from: https://www.ncbi.nlm.nih. gov/pubmed/?term=Circulation+2008\%3B118\%3A+e523-e661

8. Tarasoutchi F, Montera MW, Grinberg M, Barbosa MR, Piñeiro DJ, Sánchez CRM, Barbosa MM, Barbosa GV, et al. Diretriz Brasileira de Valvopatias - SBC 2011/I Diretriz Interamericana de Valvopatias - SIAC 2011. Arq Bras Cardiol [Internet]. 2011; [cited 2016 Jun 23]; 97(5 Supl. 1):1-67. Available from: http://publicacoes.cardiol.br/consenso/2011/ Diretriz\%20Valvopatias\%20-\%202011.pdf

9. Leon MB, Smith CR, Mack M, Miller DC, Moses JW, Svensson LG, et al.; PARTNER Trial Investigators. Transcatheter aortic-valve implantation for aortic stenosis in patients who cannot undergo surgery. $\mathrm{N}$ Engl $\mathrm{J}$ Med [Internet]. 2010; [cited 2016 Jun 24]; 363(17):1597-607. Available from: http://www.nejm.org/doi/full/10.1056/nejmoa1008232

10. Tuzcu EM, Kapadia SR, Svensson LG. "SOURCE" of enthusiasm for transcatheter aortic valve implantation. Circulation [Internet]. 2010 [cited 2016 Jun 24]; 122(1):8-10. Available from: http://circ. ahajournals. org/content/122/1/8.short

11. Lima GOP. Cuidando do cliente com distúrbio respiratório agudo: proposta de um protocolo assistencial para tomar decisões em enfermagem [dissertação]. Rio de Janeiro: Escola de Enfermagem Alfredo Pinto, Universidade Federal do Estado do Rio de Janeiro; 2006.

12. Grupo Hospitalar Conceição/Gerência de Ensino e Pesquisa. Diretrizes Clínicas/Protocolos Assistenciais: Manual Operacional. Porto Alegre: Grupo Hospitalar Conceição; 2008.

13. Grant JS, Davis LL. Selection and use of content experts for instrument development. Res Nurs Health [Internet]. 1997; [cited 2016 Jun 24]; 20(3):269-74. Available from: http://onlinelibrary.wiley.com/doi/10.1002/ (SICl)1098-240X(199706)20:3\%3C269::AID-NUR9\%3E3.0.CO;2-G/full

14. Rubio DM, Berg-Weger M, Tebb SS, Lee S, Rauch S. Objectifying content validity: conducting a content validity study in social work research. Soc Work Res [Internet]. 2003 Jun; [cited 2017 Jun 22]; 27(2):94-104. Available from: https://academic.oup.com/swr/articleabstract/27/2/94/1659075. DOI: http://dx.doi.org/10.1093/swr/27.2.94

15. Mattar FN. Pesquisa em Marketing. $3^{a}$ ed. São Paulo: Atlas; 2001.482 p.

16. Alexandre NMC, Coluci MZO. Validade de conteúdo nos processos de construção e adaptação de instrumentos de medidas. Ciênc Saúde Coletiva [Internet]. 2011 Jul [cited 2016 Aug 31]; 16(7):3061-8. Available from: http://www.scielo.br/scielo.php?script=sci_arttext\&pid=S141381232011000800006\&lng=en. DOl: http://dx.doi.org/10.1590/S141381232011000800006

17. Lynn MR. Determination and quantification of content validity. Nurs Res [Internet]. 1986 Nov/Dec; [cited 2016 Aug 31]; 35(6):382-5. Available from: https://www.ncbi.nlm.nih.gov/pubmed/3640358

18. Oguisso T. Perfil do enfermeiro de unidades ambulatoriais do INAMPS no Brasil. Rev Esc Enferm USP [Internet] 1990 Apr; [cited 2016 Jun 27]; 24(1):77-92. Available from: http://www.scielo.br/scielo.php?script=sci arttext\&pid=S0080-62341990000100077\&lng=en. DOl: http://dx.doi. org/10.1590/0080-6234199002400100077 
19. Santos APA, Camelo SHH, Santos FC, Leal LA, Silva BR. Nurses in postoperative heart surgery: professional competencies and organization strategies. Rev Esc Enferm USP [Internet]. 2016 Jun; [cited 2016 May/ Jun 27]; 50(3):474-481. Available from: http://www.scielo.br/scielo. php?script=sci_arttext\&pid=S0080-62342016000300474\&lng=en. DOI: http://dx.doi.org/10.1590/S0080-623420160000400014

20. Linch GFC, Guido LA, Pitthan LO, Umann J. Unidades de hemodinâmica: a produção do conhecimento. Rev Gaúcha Enferm (Online) [Internet]. 2009 Oct/Dec; [cited 2016 Jun 27]; 30(4):742-9. Available from: http://www.scielo.br/scielo.php?script=sci_arttext\&pid=S198314472009000400022\&lng=en. DOl: http://dx.doi.org/10.1590/S198314472009000400022

21. Martins C, Kobayashi RM, Ayoub AC, Leite MMJ. Perfil do enfermeiro e necessidades de desenvolvimento de competência profissional. Texto Contexto Enferm [Internet]. 2006 Jul/Sep; [cited 2016 Jun 27]; 15(3):472-8. Available from: http://www.scielo.br/scielo.php?script=sci arttext\&pid=S0104-07072006000300012\&lng=en. DOI: http://dx.doi. org/10.1590/S0104-07072006000300012

22. Melo RP, Moreira RP, Fontenele FC, Aguiar ASC, Joventino ES, Carvalho EC. Critérios de seleção de experts para estudos de validação de fenômenos de enfermagem. Rev Rene [Internet].2011 Apr/Jun; 12(2):42431. Available from: http://periodicos.ufc.br/rene/article/view/4254

23. Chester JG, Rudolph JL. Vital signs in older patients: age-related changes. J Am Med Dir Assoc [Internet]. 2011 Jun; [cited 2016 Jun 27];12(5):337-43. Available from: https://www.ncbi.nlm.nih.gov/ pubmed/21450180.DOI: http://dx.doi.org/10.1016/j.jamda.2010.04.009

24. Mendes KDS, Silveira RCCP, Galvão CM. Revisão integrativa: método de pesquisa para a incorporação de evidências na saúde e na enfermagem. Texto Contexto Enferm [Internet]. 2008 Oct/Dec; [cited 2016 Jun 27]; 17(4):758-64. Available from: http://www.scielo.br/scielo. php?script=sci_arttext\&pid=S0104-07072008000400018\&lng=en. DOI: http://dx.doi.org/10.1590/S0104-07072008000400018
25. Rhoney DH, Murry KR. National survey of the use of sedating drugs, neuromuscular blocking agents, and reversal agents in the intensive care unit. J Intensive Care Med [Internet]. 2003 May/Jun;18(3):139-45. Available from: https://www.ncbi.nlm.nih.gov/pubmed/?term=National +survey+of+the+use+of+sedating+drugs $\% 2 \mathrm{C}+$ neuromuscular+block ng+agents $\% 2 \mathrm{C}+$ and+reversal+agents+in+the+intensive+care+unit

26. Sousa ALS, Feijó ALF, Salgado CG, Branco RVC, Falcão CHE, Assad JAR, et al. Implante de Válvula Aórtica Percutânea: experiência inicia no estado do Rio de Janeiro. Rev Bras Cardiol [Internet]. 2010 Jan/ Feb; [cited 2016 Jun 27]; 1(23):35-42. Available from: http://sociedades. cardiol.br/socerj/revista/2010_01/a2010_v23_n01_03andre.pdf

27. Barros ALBL. Anamnese e exame físico: avaliação diagnóstica de enfermagem no adulto. Porto Alegre: Artmed; 2010

28. Mateos JCP. Marcapasso cardíaco provisório: indicações e procedimentos empregados no controle de doentes graves. Rev Bras Marcapasso Arritmia [Internet]. 1990;3(3):94-9. Available from: http://www.relampa. org.br/detalhe_artigo.asp?id $=552$

29. Smeltzer SC, Bare BG. Brunner \& Suddarth: Tratado de Enfermagem Médico-Cirúrgica. Rio de Janeiro: Guanabara Koogan; 2002. 841 p.

30. Bastos AS, Beccaria LM, Barbosa TP, Werneck AL, Silva EV Complicações em pacientes após substituição valvar aórtica percutânea. Acta Paul Enferm [Internet]. 2016 May/Jun [cited 2016 Jun 27]; 29(3):267-73. Available from: http://www.scielo.br/scielo. php?script=sci_arttext\&pid=S0103-21002016000300267\&lng=pt. DOI http://dx.doi.org/10.1590/1982-0194201600038

31. Araujo LC, Romero B. Pain: evaluation of the fifth vital sign. A theoretical reflection. Rev Dor [Internet]. 2015 Oct/Dec; [cited 2017 July 31] 16(4):291-6. Available from: http://www.scielo.br/scielo.php?script=sci arttext\&pid=S1806-00132015000400291\&lng=en. DOI: http://dx.doi. org/10.5935/1806-0013.20150060

\section{SUPPLEMENTARY MATERIAL}

The following online material is available for this article: Post tavi nursing care protocol

a This paper is part of the Master's thesis: "Nursing protocol in the percutaneous aortic valve implantation" sustained by the first author within the Graduate Program of Nursing at the State University of Rio de Janeiro. 2017 